\title{
FEATURE
}

\section{Agricultural irrigation in China}

\author{
Xiufang Zhu, Yizhan Li, Muyi Li, Yaozhong Pan, and Peijun Shi
}

$s$ the most populous country in the world, China always faces challenges for food security. The country must feed its 1.3 billion people with less than $10 \%$ of the world's arable land (Wu et al. 2010). Over the last 60 years, the population of China has increased from 0.5 to 1.3 billion, the total irrigated area has increased almost monotonically from 15.9 million ha (39.3 million ac) to 61.7 million ha (152.5 million ac), and grain output has increased from 113.2 billion $\mathrm{kg}(249.6$ billion $\mathrm{lb})$ to 571.2 billion $\mathrm{kg}(1,259.5$ billion lb) (figure 1).

Arable land and available water resources are distributed unevenly in China. To realize self-sufficiency in food production, the Chinese have undertaken large-scale programs to increase agricultural production. Efforts include using chemical pesticides and fertilizers, developing new strains of genetically modified crops, and investing in irrigation infrastructure. Among those measures, agricultural irrigation has made the largest contribution to crop yield increase and poverty reduction in rural areas (Huang et al. 2006).

Irrigation stabilizes crop production, improves crop quality, reduces rural poverty, and allows for diversification in farm production. Approximately half of the national cropland is irrigated and produces $75 \%$ of the nation's food, $80 \%$ of its cotton and oil-bearing crops, and $90 \%$ of its vegetables and fruits (Kai et al. 2006). The crop production of irrigated areas is much higher than that of nonirrigated land, especially in northwest China where the production of irrigated paddy land is about three times higher than that of nonirrigated land (table 1). Advances in agricultural science and technology (including agricultural irrigation) have allowed the total production of

Xiufang Zhu is an assistant professor, Yizhan Li and Muyi Li are graduate students, and Yaozhong Pan and Peijun Shi are professors at State Key Laboratory of Earth Processes and Resource Ecology, College of Resources Science and Technology, Beijing Normal University, Beijing, China. grain crops to increase over fivefold from 1949 (113.2 billion $\mathrm{kg}$ [249.6 billion lb]) to 2011 (571.2 billion $\mathrm{kg}[1,259.5$ billion lb]), with an annual growth rate of $6.42 \%$. The average per capita grain production in 2011 was $425 \mathrm{~kg}(937 \mathrm{lb})$ compared to $208.9 \mathrm{~kg}$ (460.6 lb) in 1949, representing a twofold increase during that period.

The role that irrigation can play in ensuring future food security is unclear. On one hand, agricultural irrigation is expected to continue to contribute to the stabilization of food prices, increases in farmers' income, and increases food supply for over 1.3 billion Chinese. Simultaneously, the potential to develop additional water resources and infrastructure in the future may be limited. Water security and water controversy among different sectors is becoming increasingly drastic. In addition, climate change is projected to worsen the situation. The warming trend is expected to continue, which is likely to accelerate evaporation and soil dryness (Sheffield and Wood 2008). Climate change also modifies precipitation geographically and temporally, placing more stress on the water and food security of China (Kitoh et al. 2005; Zhang et al. 2006; Kharin et al. 2007; Chen and Sun 2009).

\section{Figure 1}

The variation of (a) grain output, (b) effective irrigated area, total sown area, grain crops sown area, and (c) population in China between 1949 and 2011. The data before 2005 is from the China compendium of statistics 1949 to 2004 (NSBC 2005), and the data after 2005 is from the China Statistical Yearbook 2012 (NSBC 2012).

(a)

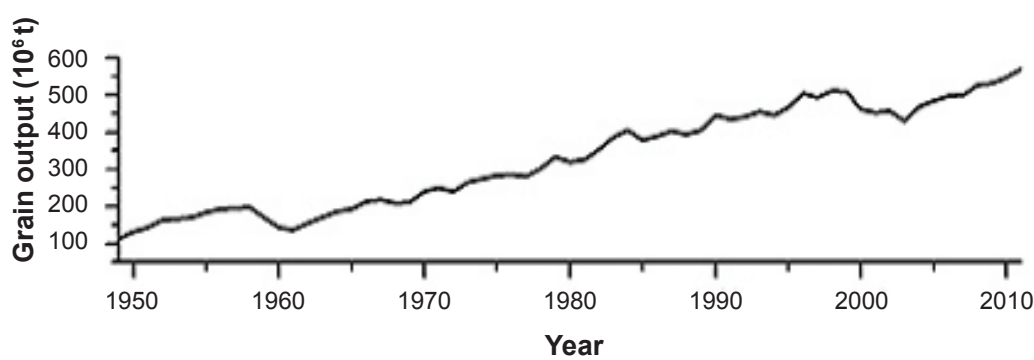

(b)

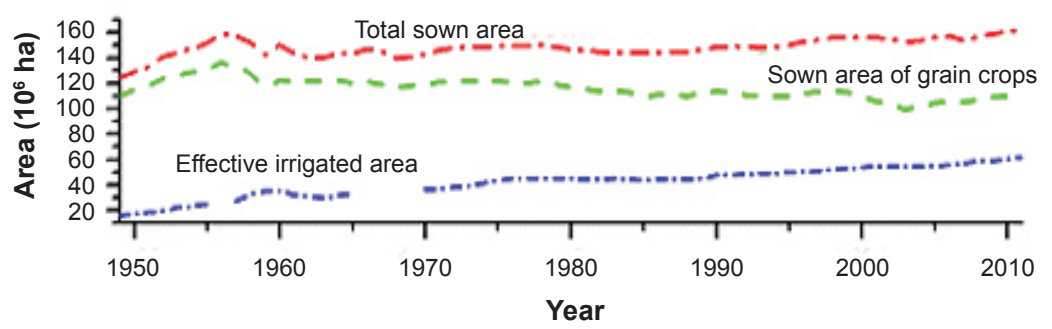

(c)

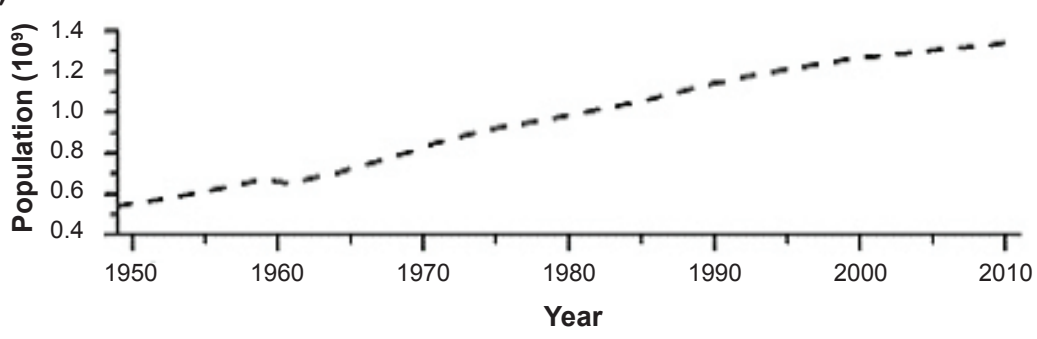




\section{THE CURRENT STATUS OF AGRICULTURAL IRRIGATION}

Effective Irrigated Area. China began to forcefully exploit water resources and develop irrigation starting at the time of the foundation of New China in 1949. The development of the effective irrigated area (EIA) can be generally divided into three phases: 1949 to 1980,1981 to 1990 , and 1991 to present.

During 1949 to 1980, a period of rapid expansion, the Chinese government invested heavily in irrigation projects such as canals, reservoirs, dams, and wells. The EIA increased dramatically from 15.9 million ha (39.3 million ac) in 1949 to 44.9 million ha (111 million ac ) in 1980, representing nearly a threefold increase (NSBC 2012). The number of mechanical and electrical wells for irrigation increased from 0.11 million in 1961 to 2.69 million in 1980 , representing a 23.6 -fold increase. The number of completed reservoirs reached 86,822 , with a total storage capacity of 413 billion $\mathrm{m}^{3}$ (90,860 billion gal).

From 1980 to 1990, the Chinese government reduced its financial expenditures of irrigation development and management. During the same period, with the fast industrialization and urbanization, more water was consumed by domestic and industrial sectors. The EIA remained stable, and by 1990 , it had decreased slightly to 47.4 million ha (117.1 million ac).

After 1990, the total EIA increased slowly because reductions in existing EIA partly offset the newly added EIA (MWRC 2009). The reasons for the observed reduction of EIA included aging and damage of structures, abortion of wells, land occupation by construction, long-term insufficiency of water sources, conversion of farmland to other usage, and others. Aging and damage to structures was the dominant factor. In 2008, the amount of EIA fell by 0.65 million ha (1.61 million ac), $37 \%$ of which was caused by aging and damage of structures (table 2 ).

The irrigated area of forestry, fruit gardens, pasture land, and others have increased over the last 10 years (figure 2). The total irrigated area of forestry, fruit gardens, and pasture land was 1.1, 1.6, and 1.0 million ha $(2.7,4.0$, and 2.5 million ac) and 1.7, 2.1, and 1.2 million ha (4.2, 5.2. and 3.0 million ac) in 2000 and 2008 , respectively (MWRC 2009).
Meanwhile, the direction of irrigation development changed from extensive management to intensive management. More emphasis was put on water-saving irrigation, optimizing irrigation management, and modernization and maintenance of large-scale irrigation systems. As of 2011 , there were up to 348 pieces of large irrigation area that spread over 20,000 ha $(49,420 \mathrm{ac})$ with an effective irrigated area of 15.8 million ha (39 million ac) (NSBC 2012). The total area of water-saving irrigation had grown to 24.4 million ha $(60.3$ million ac) by 2008 (MWRC 2009), taking up $41.8 \%$ of the total EIA, in which the total area of sprinkler irrigation, micro-irrigation, low-pressure pipe irrigation, and canal lining irrigation were 2.8 , 1.2, 5.9, and 1.0 million ha $(6.9,3.0,14.6$, and 2.5 million ac), respectively (figure 3 ).

\section{Table 1}

The comparison analysis of crop production with and without irrigation in different districts of China (Wu 2010).

\begin{tabular}{|c|c|c|c|c|c|}
\hline \multirow[b]{2}{*}{ Area } & \multirow{2}{*}{$\begin{array}{l}\text { Unirrigated land } \\
\text { Production } \\
\left(\mathrm{kg} \mathrm{ha}^{-1}\right)\end{array}$} & \multicolumn{2}{|c|}{ Irrigated paddy land } & \multicolumn{2}{|c|}{ Irrigated dry land } \\
\hline & & $\begin{array}{l}\text { Production } \\
\left(\mathrm{kg} \mathrm{ha}^{-1}\right)\end{array}$ & $\begin{array}{l}\text { Growth } \\
\text { rate (\%) }\end{array}$ & $\begin{array}{l}\text { Production } \\
\left(\mathrm{kg} \mathrm{ha}^{-1}\right)\end{array}$ & $\begin{array}{l}\text { Growth } \\
\text { rate (\%) }\end{array}$ \\
\hline Northeast & $2,235.00$ & $5,085.00$ & 127.52 & $3,600.00$ & 61.07 \\
\hline Northwest & $1,117.50$ & $4,695.00$ & 320.13 & $3,052.50$ & 173.15 \\
\hline Huanghuaihai basin & $2,235.00$ & $7,305.00$ & 226.85 & $6,075.00$ & 171.81 \\
\hline Lower Yangtze region & $2,685.00$ & $2,685.00$ & 186.59 & $4,777.50$ & 77.93 \\
\hline Southeast & $3,135.00$ & $7,785.00$ & 148.33 & $7,050.00$ & 124.88 \\
\hline Southwest & $3,075.00$ & $7,005.00$ & 127.80 & $6,115.50$ & 98.88 \\
\hline
\end{tabular}

\section{Table 2}

Reasons of reduction of effective irrigated area (EIA) from 2000 to 2008.

\begin{tabular}{|c|c|c|c|c|c|c|c|}
\hline \multirow[b]{2}{*}{ Year } & \multirow[b]{2}{*}{$\begin{array}{l}\text { Reduction } \\
\text { of EIA }\left(10^{3} \mathrm{ha}\right)\end{array}$} & \multicolumn{6}{|c|}{ Reasons for reduction of EIA ( $\left.10^{3} \mathrm{ha}\right)$} \\
\hline & & $\begin{array}{l}\text { Aging and damage } \\
\text { of structures }\end{array}$ & $\begin{array}{l}\text { Abortion } \\
\text { of wells }\end{array}$ & $\begin{array}{l}\text { Land occupation } \\
\text { by construction }\end{array}$ & $\begin{array}{l}\text { Long-term insufficiency } \\
\text { of water sources }\end{array}$ & $\begin{array}{l}\text { Converting farmland } \\
\text { to other usage }\end{array}$ & Others \\
\hline 2001 & 665.58 & 306.33 & 10.88 & 112.93 & - & 48.00 & 187.44 \\
\hline 2002 & 901.21 & 325.95 & 12.27 & 197.74 & - & 141.17 & 224.09 \\
\hline 2005 & 697.34 & 237.31 & 14.91 & 199.94 & - & 68.43 & 176.76 \\
\hline 2006 & 796.86 & 183.12 & - & 123.67 & 100.06 & 39.69 & 350.32 \\
\hline 2007 & 608.63 & 192.26 & - & 125.89 & 54.62 & 51.93 & 183.93 \\
\hline 2008 & 648.41 & 239.55 & - & 97.04 & 96.52 & 22.95 & 192.35 \\
\hline
\end{tabular}




\section{Figure 2}

Agricultural irrigated area for farmland, forestry, fruit gardens, pasture land, and others in (a) 2000 and (b) 2008.

(a)

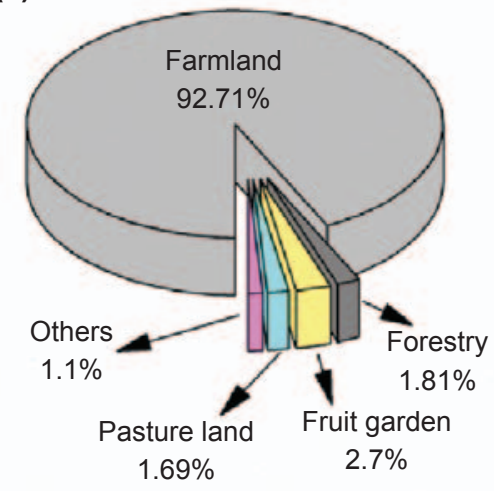

(b)

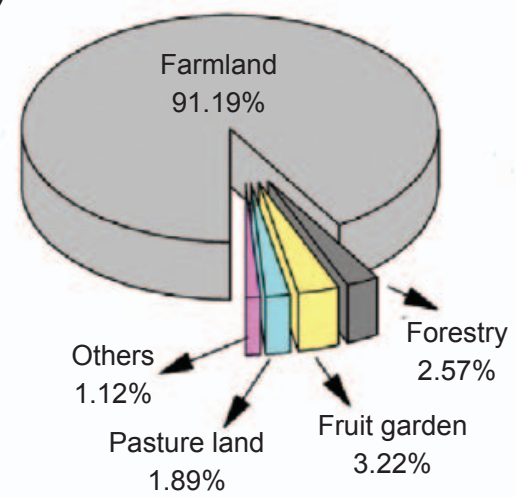

accounting for $19.5 \%$ of national water resources (3,090.64 billion $\mathrm{m}^{3}$ [679,940.8 billion gal]) in 2010 (NSBC 2012). At that time, the amounts of surface water supply, underground water supply, and other sources of supply were $488.16,110.73$, and 3.31 billion $\mathrm{m}^{3}$ (107,395.2, 24,360.6, and 728.2 billion gal), respectively.

Like the EIA, the level of agricultural water consumption went through three phases (figure 4b). Between 1949 and 1980, agricultural water consumption showed a clear upward trend along with the great expansion of EIA, increasing by nearly fourfold from 100.1 billion $\mathrm{m}^{3}$ (22,022 billion gal) to about 369.9 billion $\mathrm{m}^{3}(81,378$ billion gal). It did not change significantly over the subsequent 10 years. Since 1991, agricultural water consumption shows a slight downward trend, falling to 368.91 billion $\mathrm{m}^{3}(81,160.2$ billion gal) as of 2010 .

In addition to the changing trends in the total quantity of agricultural water consumption, the structure of agricultural water use is also shifting. The use of irrigation water for farmland is decreasing while the use of irrigation water for fisheries, pasture land, and forestry/fruit production is increasing. In 1980, the proportions of irrigation for farmland, forestry/fruit production, pasture, and fisheries were $94.4 \%$, $2 \%, 1.4 \%$, and $2.2 \%$ respectively; in 2000 they were $91.6 \%, 3.2 \%, 1.7 \%$, and $3.5 \%$ (Wang et al. 2010a).

\section{THE CHALLENGES OF AGRICULTURAL IRRIGATION}

Water Shortage in China. China's total annual available fresh water volume is 2,325.85 billion $\mathrm{m}^{3}$ (511,687 billion gal) (NSBC 2012), accounting for about $7 \%$ of the world's total fresh water resources. The water resource is large in absolute value, ranking sixth in the world, but the water resource per capita is around $1,856 \mathrm{~m}^{3}$ (408,320 gal), only about $25 \%$ of the world average (Yuan et al. 2008), ranking 109th in the world. Moreover, only $39.3 \%$ of the existing fresh water is accessible. Among the 31 provinces in China, water resource per capita in 16 provinces is lower than the internationally accepted definition of water scarcity $\left(1,000 \mathrm{~m}^{3}[220,000 \mathrm{gal}]\right)$; the average per capita water supplies in 6 water use to total water consumption shows a decreasing trend due to rapidly increasing nonagricultural demands for water. In 1949, the proportion of agricultural water use was about $90 \%$ of the total. It decreased to $61.3 \%$ by 2010 but remains larger than the proportion of water used by nonagricultural departments (figure 4a). The national total water supply capacity is 602.2 billion $\mathrm{m}^{3}(132,484$ billion gal), 


\section{Figure 4}

Changes of (a) total water use and proportion of annual agricultural water use to total water use and (b) annual water consumption structure in China.

(a)

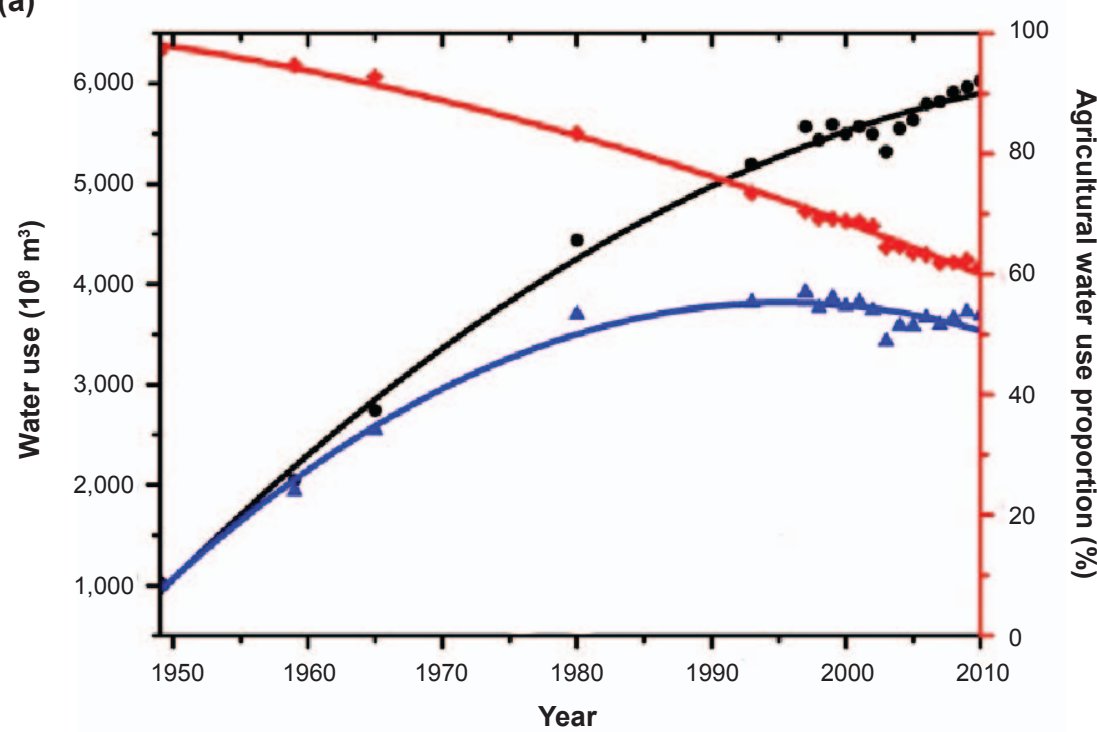

Legend

- Total water use

^ Agricultural water use

- Agricultural water use proportion

(b)

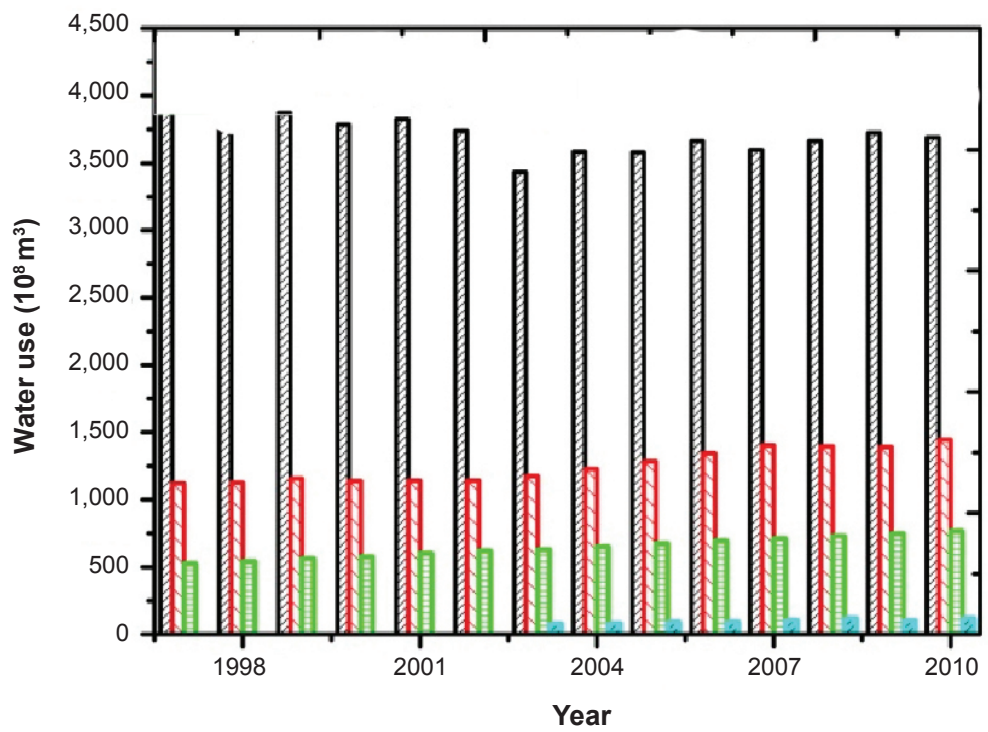

Legend
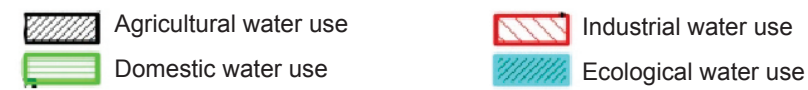

provinces are lower than $500 \mathrm{~m}^{3}(110,000$ gal) (Zhang et al. 2009).

Uneven Distribution of Water

Resources. The distribution of water resources is spatially and seasonally uneven. About $81 \%$ of water resources are found the Huang-Huai-Hai region is estimated to have the greatest potential for food production in China but is limited by its access to less than $10 \%$ of the total national water resources (Liu 2007). The amount of water per hectare of cultivated land in southern China is $28,695 \mathrm{~m}^{3}(6.3 \mathrm{mil}-$ lion gal), compared to only $9,645 \mathrm{~m}^{3}(2.1$ million gal) in northern China (Zhang et al. 2009). The average supply of groundwater is about four times greater in the south than in the north. In addition, the distribution of water resources is seasonally uneven. Precipitation occurs mainly in spring and summer. In most areas of China, the accumulated rainfall over those four consecutive months accounts for over $70 \%$ of annual rainfall (figure 5 ).

Deterioration of Water Quality. According to the results of a 2011 water quality assessment on sections of river totaling over $189,000 \mathrm{~km}(117,444.6 \mathrm{mi})$, $35.8 \%$ showed water quality worse than the class-III standard (MWRC 2011). The most important indicator for identifying poor water quality levels was nitrogen $(\mathrm{N}$; in the form of ammonia $\left.\left[\mathrm{NH}_{3}\right]\right)$, followed by organic materials (biochemical oxygen demand and chemical oxygen demand). The water quality of large lakes is also declining due to both point and nonpoint source emissions. In 2011, a total of 103 large lakes, totaling 2.7 million ha (6.7 million ac), were evaluated. The water quality in $41.2 \%$ of the tested water body area fell below the class-III standard (MWRC 2011). In the same year, a total of 471 major reservoirs were evaluated, and the water quality in $18.9 \%$ of the tested reservoirs was also below the class-III standard (MWRC 2011).

Groundwater Depletion. Excessive extraction of groundwater aggravates the freshwater security problem, which has already reached very serious levels. For example, the lower reaches of the Yellow River in northern China have dried up in the winter months several times since 1972 (Chen and Tang 2005; Deng et al. 2006). Moreover, many inland rivers in the Hexi region, which are used to supply irrigation water, are also reported to have dried up (Ji et al. 2006). The groundwater exploitation rate by the agricultural sector in Ningiin County in the Shandong Province of China was reported to be $113 \%$ (Zhen and 


\section{Figure 5}

Distribution of cropland and total amount of water resources in China. There are six water resource regions in northern China and four water resource regions in southern China.

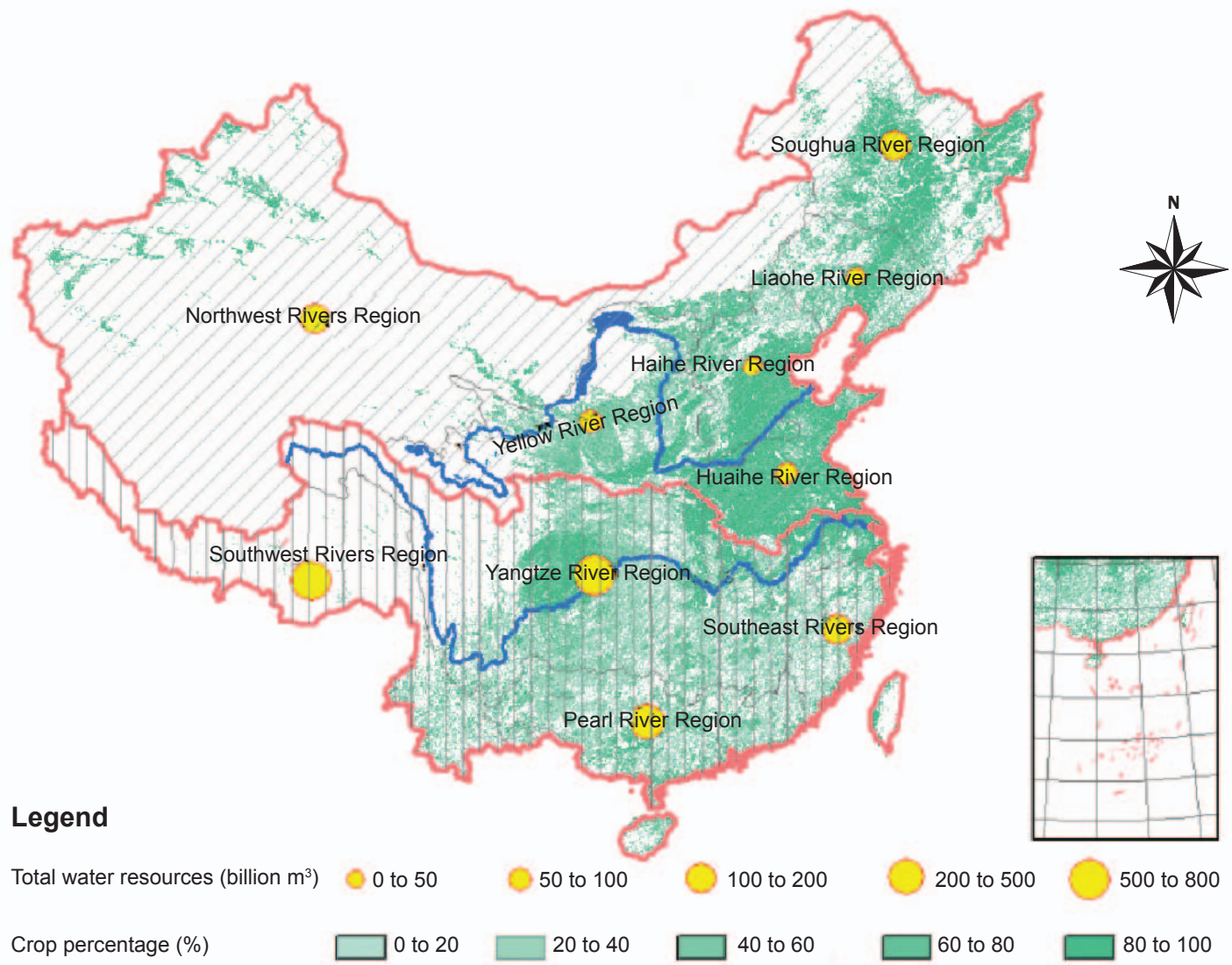

Routray 2002). Agriculture was the major consumer of groundwater and caused over $80 \%$ of the total groundwater withdrawal in the Hebei Plain (Xu et al. 2005). Irrigation based on groundwater has caused the groundwater level of the North China Plain in 2001 to decrease by nearly twothirds since the 1970s (Zhang et al. 2003).

Low Water Use Efficiency. Although irrigation methods are improving, water waste during agricultural use is still extremely high and calls for urgent reduction. Flood irrigation is still the predominant irrigation method. Border irrigation and furrow irrigation are popular irrigation methods for drought-resistant crops, such as wheat, maize, and cotton, while check irrigation is the dominant technique for irrigating rice in China. More than $80 \%$ of the irrigation facilities in the large to medium scale irrigation district have operated for over 30 years. Many irrigation systems were not properly maintained, making them inefficient and providing a poor service to farmers. Until
2009 , about $75 \%$ of drainage pumping stations failed to work due to severe aging. About $50 \%$ of small- or medium-sized canals need to be repaired and upgraded (Peng and Ai 2012).

Chinese irrigation systems are inefficient, though there is variation from province to province (figure 6). The average water use efficiency is about $47 \%$, and efficiency is considerably less in the provinces in southern China where water resources are relatively abundant. The water use efficiency of well irrigation areas is relatively high (about 60\%), while that of the canal irrigation regions is lower than $40 \%$, compared to $70 \%$ to $90 \%$ in most developed countries. Nearly 60\% of agricultural water was wasted during the delivery process from irrigation water sources to irrigated fields. In addition, Chinese current water use for grain crop production is $1 \mathrm{~kg} \mathrm{~m}^{-3}\left(2.205 \mathrm{lb} \mathrm{gal}^{-1}\right.$ ) on average (Wu 2010), which is about $50 \%$ of the efficiency observed in many developed countries.
Impacts of Climate Change. Climate change has and will continue to have an impact on agricultural yields in China. Thermal and moisture conditions are two key components that affect crop production. Observational evidence shows climate changes have already occurred in China. During the past 50 years, the average surface air temperature across China increased by $1.2^{\circ} \mathrm{C}\left(34.2^{\circ} \mathrm{F}\right)$ (Piao et al. 2010); most of the temperature increase took place after 1980 (Ding et al. 2007). The warming trend was most significant in northern China and in winter season $\left(0.04^{\circ} \mathrm{C} \mathrm{y}^{-1}\left[32.07^{\circ} \mathrm{F} \mathrm{yr}^{-1}\right]\right)$ (Ren 2007; Piao et al. 2010). There have been no statistically significant shifts in the trend of annual precipitation across China since 1960, but variations among regions are considerable (Piao et al. 2010). Precipitation levels have decreased by $12 \%$ in northern China and northeastern China since 1960 (Piao et al. 2010). In contrast, southern China experienced more rainfall 
during both summer and winter. Since the 1950 s, total precipitation has risen 20 to 60 $\mathrm{mm}$ ( 0.8 to $2.4 \mathrm{in}$ ) each decade on average in southern and southwestern China (Ren 2007). Accordingly, droughts in northern and northeastern China have become more severe, and flooding in the middle and lower reaches of the Yangtze River and southeastern China have intensified (PRC 2007).

The impacts of climate change on crops are complex due to regional conditions, crop varieties, climate variability, and other factors. In northeastern China, increasing temperatures benefit agricultural production, enabling a significant northward expansion of rice planting in Heilongjiang Province from 0.22 million ha $(0.54$ million ac) in the early 1980 s to 2.25 million ha (5.56 million ac) in 2007 (Piao et al. 2010). Regional climate warming also lengthened the growing season of cotton in northwestern China by nine days over the period from 1983 to 2004 (Wang et al. 2008). Overall, rain-fed crops are believed to be much more severely affected by climate change than irrigated crops (Wang et al. 2009a). Maize yields and wheat yields were reported to have decreased while rice yields increased due to a warming climate. (Tao et al. 2008; You et al. 2009). Climate warming will surely continue in the coming years although there are considerable uncertainties about its pace and magnitude. The changes in precipitation geographically and seasonally will have a significant influence on irrigation requirements and are projected to make water shortages and agricultural disasters (drought/flooding) more serious, consequently negatively affecting crop production (Lin et al. 2006; Wang et al. 2009a) .

Other Challenges. Some other factors also have an impact on agricultural irrigation in China. First, water consumption is ever increasing along with population growth, economic development, and a rising standard of living. The competition between the agricultural, industrial, and ecoenvironmental sectors for limited water supplies is becoming increasingly acute, and the proportion of water used for agriculture is showing a decreasing trend. Second, the rapid expansion of urban areas is consuming more and more arable land, and this land, including areas equipped with irrigation facilities, is being swallowed up by cities (Larson 2013). In terms of data from China's Ministry of Land and Resources, more than 860,000 ha (2.1 million ac) of arable land were transformed by urban development each year on average during the period from 1998 to 2006. Especially in southern China, which has abundant water and fertile soils, available cropland has shrunk significantly during past decades owing to urbanization and the expansion of large-scale industry (Liu et al. 2008; Deng et al. 2009; Liu and Tian 2010).Third, China is one of the countries suffering from the most serious soil and water loss in the world. More than 66,000 ha $(163,086 \mathrm{ac})$ of arable land is claimed by soil and water loss every year (Zhen 2004). Soil erosion in the rivers, lakes, and reservoirs leads to sedimentation, reducing the storage capacity of water projects as well as the flood carrying capacity of natural rivers.

\section{POTENTIAL METHODS FOR ADAPTING TO IRRIGATION REQUIREMENTS}

To achieve sustainable economic development and satisfy increased requirements needed to supply food for an expanding

\section{Figure 6}

Irrigation water use efficiency in China (the data are from the National Irrigation Water Use Efficiency Measure and Analysis Report 2006).

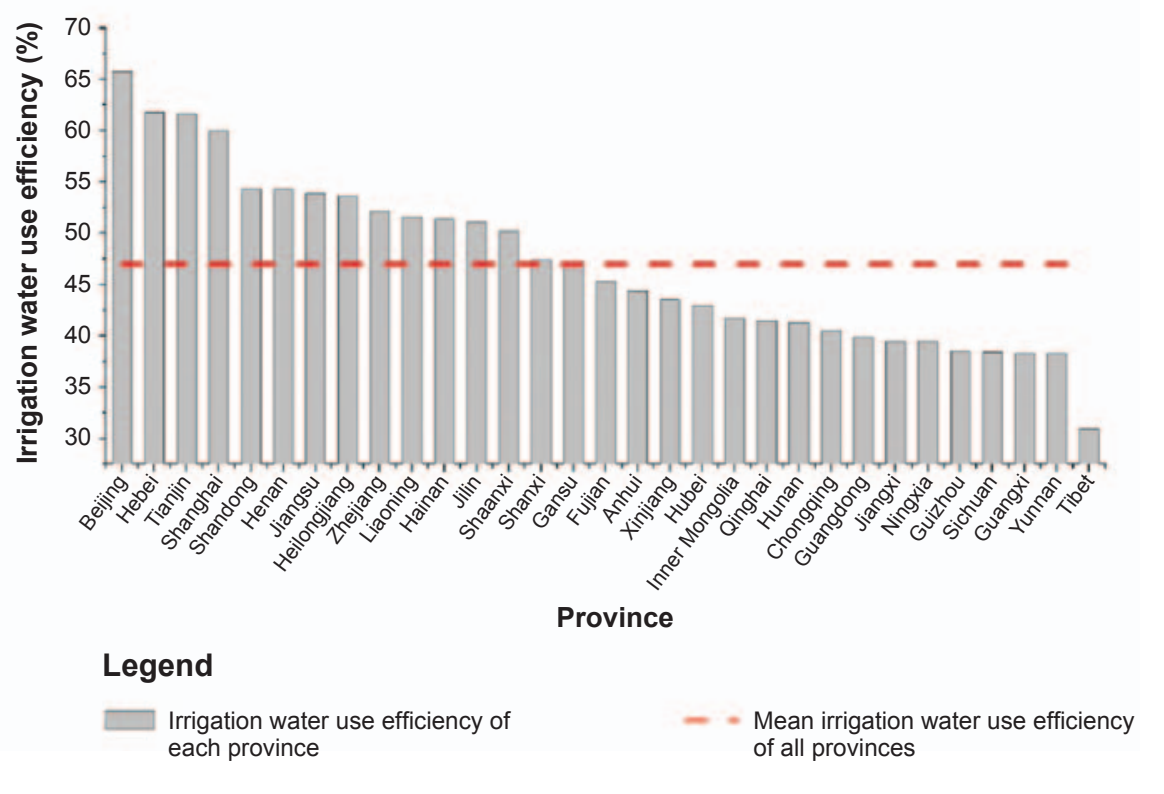

population, the government must develop appropriate water management strategies to harmonize the water use structure among different sectors as well as within the agricultural sector (Wang and Gao 2002; Chen et al. 2005; Fang et al. 2007; Wei et al. 2008). There is plenty of room for improvement in water use efficiency (Wang 2010). Methods for improving water use efficiency include regulating transpiration efficiency, enhancing soil water utilization efficiency, reducing soil evaporation ( $\mathrm{Li}$ et al. 2008), optimizing irrigation scheduling (Wang et al. 2001), developing water-saving irrigation (Gao et al. 2002; Li 2006; Zhang et al. 2006), and investing in water infrastructure, irrigation systems, and irrigation equipment.

Water distribution is uneven both temporally and spatially in China. The Chinese government has set up the Southto-North Water Diversion Project in an attempt to transfer the water from wet southern China to dry northern China. However, the benefits and disadvantages of this project are disputed (Wang and $\mathrm{Ma}$ 1999; Wang et al. 2009b; Zhang 2009). In the future, the Chinese government will keep investing in hydraulic projects, but more attention should be paid to the com- 
prehensive assessment of the profits and costs-especially the potential ecological costs - of such projects (Yin and Yang 2011). Meanwhile, adjusting planting and harvest dates based on temporal climate change effects, such as precipitation seasons, might be a useful adaptation to variations in temporal water distribution.

Currently, farmers have little incentive to save water, and not all of them realize that water is a finite resource (Wang et al. 2006; Bluemling et al. 2010). They also lack the knowledge to optimize their irrigation schedule and apply water-saving measures. Therefore, the Chinese government needs to create organizations to help farmers develop water-saving technologies and enhance their consciousness of water conservation. The water price reform is helpful for controlling water consumption, but it must be implemented in cooperation with other water management policies.

In addition, developing droughtresistant crops, planting new strains of genetically modified crops and water efficient cultivars (Hu et al. 2006; Zhang et al. 2010), shifting sowing dates, and adjusting crop distribution and structure would also help to reduce water consumption and keep agricultural production high (Li et al. 2010; Tao and Zhang 2010; Wang et al. 2010b; Wang et al. 2011).

\section{SUMMARY}

During the past decade, the Chinese government launched a series of programs to enhance the sustainable use of water resources and has made great strides in water-saving strategies. The task of fighting water shortage remains challenging, however, and will be increasingly difficult in the future because of increased irrigation requirements due to climate change and other factors. Various measures must work together to deal with irrigation requirement increases. Improving water resource management infrastructure; repairing old irrigation systems; investing in hydraulic projects; promoting watersaving technologies; adjusting agricultural water structures; increasing harmonization among agriculture, forestry, herding, and fisheries as well as water consumption by grain crops, cash crops, and grazing grass; enhancing agriculture water use efficiency; and planting more water efficient cultivars can all contribute to sustainable future management of water resources.

\section{REFERENCES}

Bluemling, B., H. Yang, and H.J. Mosler. 2010 Adoption of agricultural water conservation practices - A question of individual or collective behaviour? The case of the North China Plain. Outlook on Agriculture 39(1):7-16.

Chen, H.P., and J.Q. Sun. 2009. How the "best" models project the future precipitation change in China. Advances in Atmospheric Sciences 26(4):773-782

Chen, Y., and H. Tang. 2005. Desertification in north China: background, anthropogenic impacts and failures in combating it. Land Degradation \& Development 16:367-376.

Chen,Y., D.Q. Zhang,Y.B. Sun, X.N. Liu, N.Z.Wang, and H.H.G. Savenije. 2005. Water demand management: A case study of the Heihe River Basin in China. Physics and Chemistry of the Earth 30(6-7):408-419.

Deng, J.S., K. Wang, Y. Hong, and J.G. Qi. 2009. Spatio-temporal dynamics and evolution of land use change and landscape pattern in response to rapid urbanization. Landscape and Urban Planning 92(3-4):187-198.

Deng, X-P., L. Shan, H. Zhang, and N.C. Turner. 2006. Improving agricultural water use efficiency in arid and semiarid areas of China. Agricultural Water Management 80:23-40.

Ding, Y.H., G.Y. Ren, Z.C. Zhao, Y. Xu, Y. Luo, Q.P. Li, and J. Zhang. 2007. Detection, causes and projection of climate change over China: An overview of recent progress. Advances in Atmospheric Sciences 24(6):954-971.

Fang, C.L., C. Bao, and J.C. Huang. 2007. Management implications to water resources constraint force on socio-economic system in rapid urbanization: A case study of the hexi corridor, NW China. Water Resources Management 21(9):1613-1633

Gao, Q.Z., H.L. Du, and R.P. Zu. 2002. The balance between supply and demand of water resources and the water-saving potential for agriculture in the Hexi corridor. Chinese Geographical Science 12(1):23-29.

Hu, Y.C., H.B. Shao, L.Y. Chu, and W. Gang. 2006. Relationship between water use efficiency (WUE) and production of different wheat genotypes at soil water deficit. Colloids and Surfaces B-Biointerfaces 53(2):271-277.
Huang, Q.Q., S. Rozelle, B. Lohmar, J.K. Huang, and J.X. Wang. 2006. Irrigation, agricultural performance and poverty reduction in China. Food Policy 31(1):30-52.

Ji, X.B., E.S. Kang, R.S. Chen, W.Z. Zhao, Z.H. Zhang, and B.W. Jin. 2006. The impact of the development of water resources on environment in arid inland river basins of Hexi region, Northwestern China. Environmental Geology 50(6):793-801.

Kai, W.U., L.U. Bu, and Y. Zhang. 2006. The recent developments and the contributation of rarmland irrigation to national grain safeness in China. Journal of Irrigation and Drainage 25(4):7-10.

Kharin, V.V., F.W. Zwiers, X.B. Zhang, and G.C. Hegerl. 2007. Changes in temperature and precipitation extremes in the IPCC ensemble of global coupled model simulations. Journal of Climate 20(8):1419-1444.

Kitoh, A., M. Hosaka, Y. Adachi, and K. Kamiguchi. 2005. Future projections of precipitation characteristics in East Asia simulated by the MRI CGCM2. Advances in Atmospheric Sciences 22(4):467-478.

Larson, C. 2013. Losing arable land, China faces stark choice: Adapt or go hungry. Science 339(6120):644-645.

Li, S., S.H. Kang, F.S. Li, and L. Zhang. 2008. Evapotranspiration and crop coefficient of spring maize with plastic mulch using eddy covariance in northwest China. Agricultural Water Management 95(11):1214-1222.

Li, S.A., T. Wheeler, A. Challinor, E.D. Lin, Y.L. $\mathrm{Xu}$, and H. Ju. 2010. Simulating the impacts of global warming on wheat in China using a large area crop model. Acta Meteorologica Sinica 24(1):123-135.

Li, Y.H. 2006. Water saving irrigation in China. Irrigation and Drainage 55(3):327-336

Lin, E., Y. Xu, J. Jiang, Y. Li, X. Yang, J. Zhang, C. Li, S. Wu, Z. Zhao, J. Wu, H. Ju, C. Yan, S. Wang, Y. Liu, B. Du, C. Zhao, B. Qin, C. Liu, C. Huang, X. Zhang, and S. Ma. 2006. National asessment report of climate change (II): Climate change impacts and adaptation. Advances in Climate Change Research 2(2):51-56.

Liu, M.L., and H.Q. Tian. 2010. China's land cover and land use change from 1700 to 2005 : Estimations from high-resolution satellite data and historical archives. Global Biogeochemical Cycles 24:18.

Liu, W. 2007. Analysis on the Problem of Agricultural Water Resource in China. Ecological Economy (1):63-66

Liu, Y.S., L.J. Wang and H.L. Long. 2008. Spatiotemporal analysis of land-use conversion in the 
eastern coastal China during 1996-2005. Journal of Geographical Sciences 18(3):274-282.

MWRC (Ministry of Water Resources, P.R. China). 2009. China Water Statistical Yearbook 2009. Beijing: China WaterPower Press.

MWRC. 2011. China Water Resources Bulletin 2011. Beijing: China WaterPower Press.

NSBC (National Statistical Bureau, P.R. China). 2005. China Compendium of Statistics, 19492004. Beijing: China Statistics Press.

NSBC. 2012. China Statistical Yearbook 2012. Beijing: National Statistical Bureau.

Peng, S.Z., and L.K. Ai. 2012. Improving irrigation water use coefficient and ensuring national food and water safety. Water Resources Protection 28(3):79-82.

Piao, S.L., P. Ciais, Y. Huang, Z.H. Shen, S.S. Peng, J.S. Li, L.P. Zhou, H.Y. Liu, Y.C. Ma, Y. H. Ding, P. Friedlingstein, C.Z. Liu, K. Tan, Y.Q. Yu, T.Y. Zhang, and J.Y. Fang. 2010. The impacts of climate change on water resources and agriculture in China. Nature 467(7311):43-51.

PRC (People's Republic of China). 2007. China's National Assessment Report on Climate Change. Beijing: Science Publishing House.

Ren, G. 2007. Climate Change and Water Resources in China. Beijing: China Meteorological Press.

Sheffield, J., and E.F. Wood. 2008. Projected changes in drought occurrence under future global warming from multi-model, multi-scenario, IPCC AR4 simulations. Climate Dynamics 31(1):79-105.

Tao, F., M. Yokozawa, J. Liu, and Z. Zhang. 2008. Climate-crop yield relationships at provincial scales in China and the impacts of recent climate trends. Climate Research 38(1):83-94.

Tao, F.L., and Z. Zhang. 2010. Adaptation of maize production to climate change in North China Plain: Quantify the relative contributions of adaptation options. European Journal of Agronomy 33(2):103-116.

Wang, H.L., Y.T. Gan, R.Y. Wang, J.Y. Niu, H. Zhao, Q.G. Yang, and G.C. Li. 2008. Phenological trends in winter wheat and spring cotton in response to climate changes in northwest China. Agricultural and Forest Meteorology 148(89):1242-1251.

Wang, H.X., L. Zhang, W.R. Dawes, and C.M. Liu. 2001. Improving water use efficiency of irrigated crops in the North China Plain - measurements and modelling. Agricultural Water Management 48(2):151-167.

Wang, J.X., R. Mendelsohn, A. Dinar, J.K. Huang, S. Rozelle, and L.J. Zhang. 2009a. The impact of climate change on China's agriculture. Agricultural Economics 40(3):323-337.
Wang, J.X., Z.G. Xu, J.K. Huang, and S. Rozelle. 2006. Incentives to managers or participation of farmers in China's irrigation systems: Which matters most for water savings, farmer income, and poverty? Agricultural Economics 34(3):315-330.

Wang, L.S., and C. Ma. 1999. A study on the environmental geology of the Middle Route Project of the South-North water transfer. Engineering Geology 51(3):153-165.

Wang, M., Y.P. Li, W.Ye, J.F. Bornman, and X.D. Yan. 2011. Effects of climate change on maize production, and potential adaptation measures: A case study in Jilin Province, China. Climate Research 46(3):223-242.

Wang, W., J.R. Dai, Y.S. Liang, Y.X. Huang, and G.C. Coles. 2009b. Impact of the South-to-North Water Diversion Project on the transmission of Schistosoma japonicum in China. Annals of Tropical Medicine and Parasitology 103(1):17-29.

Wang, X.Q., and Q.Z. Gao. 2002. Sustainable development and management of water resources in the Hei River basin of north-west China. International Journal of Water Resources Development 18(2):335-352.

Wang, X.Y. 2010. Irrigation water use efficiency of farmers and its determinants: Evidence from a survey in northwestern China. Agricultural Sciences in China 9(9):1326-1337.

Wang, Y.B., P.T. Wu, X.N. Zhao, and J.L. Li. 2010 a. Development tendency of agricultural water structure in China. Chinese Journal of EcoAgriculture 18(2):399-404 (In Chinese).

Wang, Y.B., P.T. Wu, X.N. Zhao, J.L. Li, L. Lv, and H.B. Shao. 2010b. The optimization for crop planning and some advances for water-saving crop planning in the semiarid Loess Plateau of China. Journal of Agronomy and Crop Science 196(1):55-65.

Wei, Y.C., H. Miao, and Z.Y. Ouyang. 2008. Environmental water requirements and sustainable water resource management in the Haihe River Basin of North China. International Journal of Sustainable Development and World Ecology 15(2):113-121.

Wu, P.T. 2010. Strategic considerations for Chinese agricultural water and food safety: Issues, challenges and suggestions. African Journal of Biotechnology 9(33):5251-5261.

Wu, P.T., J M. Jin, and X.N. Zhao. 2010. Impact of climate change and irrigation technology advancement on agricultural water use in China. Climatic Change 100(3-4):797-805.

Xu, Y.Q., X.G. Mo, Y.L. Cai, and X.B. Li. 2005. Analysis on groundwater table drawdown by land use and the quest for sustainable water use in the Hebei Plain in China. Agricultural Water Management 75(1):38-53.

Yin, X.A., and Z.F.Yang. 2011. Development of a coupled reservoir operation and water diversion model: Balancing human and environmental flow requirements. Ecological Modelling 222(2):224-231.

You, L., M.W. Rosegrant, S. Wood, and D. Sun. 2009. Impact of growing season temperature on wheat productivity in China. Agricultural and Forest Meteorology 149(6-7):1009-1014.

Yuan,W., S. Lianxi, L.I. Ke, and S.U.N. Hongyan. 2008. Analysis of present situation of water resources and countermeasures for sustainble development in China. Journal of Water Resources and Water Engineering 19(3):10-14.

Zhang, B.C., F.M. Li, G.B. Huang, Z.Y. Cheng, and Y.H. Zhang. 2006. Yield performance of spring wheat improved by regulated deficit irrigation in an and area. Agricultural Water Management 79(1):28-42.

Zhang, L.P., J. Xia, and Z.F. Hu. 2009. Situation and problem analysis of water resource security in china. Resources and Environment in the Yangtze Basin 18(2):116-120.

Zhang, Q.F. 2009. The South-to-North Water Transfer Project of China: Environmental implications and monitoring strategy. Journal of the American Water Resources Association 45(5):1238-1247.

Zhang, X.Y., S.Y. Chen, H.Y. Sun, Y.M. Wang, and L.W. Shao. 2010. Water use efficiency and associated traits in winter wheat cultivars in the North China Plain. Agricultural Water Management 97(8):1117-1125.

Zhang, X.Y., D. Pei, and C.S. Hu. 2003. Conserving groundwater for irrigation in the North China Plain. Irrigation Science 21(4):159-166.

Zhang, Y., Y.L. Xu, W.J. Dong, L.J. Cao, and M. Sparrow. 2006. A future climate scenario of regional changes in extreme climate events over China using the PRECIS climate model. Geophysical Research Letters 33(24):6.

Zhen, L. 2004. Soil and Water Conservation in China. Proceedings of the Ninth International Symposium on River Sedimentation.

Zhen, L., and J.K. Routray. 2002. Groundwater resource use practices and implications for sustainable agricultural development in the North China Plain: A case study in Ningin County of Shandong Province, PR China. International Journal of Water Resources Development 18(4):581-593. 